DOI: https://doi.org/10.31933/dijms.v2i5

Received: $12^{\text {nd }}$ May 2021, Revised: $25^{\text {th }}$ May 2021, Publish: $7^{\text {th }}$ June 2021

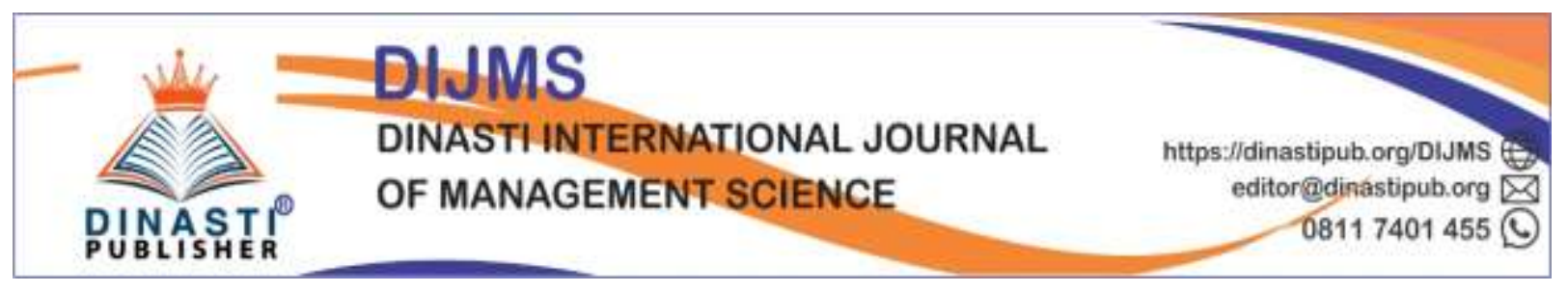

\title{
THE IMPROVE SMALL AND MEDIUM ENTERPRISES PERFORMANCE WITH HOLISTIC MARKETING MODELS
}

\begin{abstract}
Abdullah Muksin
Faculty of Economics and Business UPI Y.A.I, Pangeran. Diponegoro street, $74^{\text {th }}$, Jakarta, abydudung63@gmail.com
\end{abstract}

\section{Corresponding Author: First Author}

\begin{abstract}
This study focuses on improving the performance of SMEs after using a holistic marketing model in their business. The unit of analysis in this research is UKM players who live in Bekasi, West Java. Hypothesis testing with path analysis and using SEM and Lisrel 8.80 software. This study produces a holistic marketing model that is effective, easy to understand and use to improve Small and Medium Enterprises in Indonesia. The results of this study prove that Relations Marketing has a positive and significant effect on the performance of SMEs, especially in building relationships with distributors. Integrated marketing has a negative and insignificant effect on the performance of SMEs, internal marketing has a positive but insignificant effect on the performance of SMEs, while Performance Marketing has a positive and significant effect on the performance of SMEs. Taken together, the holistic marketing model (relations marketing, integrated marketing, internal marketing, performance marketing) has a positive and significant effect on the performance of SMEs. The dominant variable affecting the performance of SMEs is Relations marketing.
\end{abstract}

Keywords: Relations marketing, Integrated marketing, Internal marketing, Performance marketing, SME Performance.

\section{INTRODUCTION}

The main problems of Bekasi SME, especially in sub-districts that have low LQ value. Potential of SMEs such as South Bekasi, North Bekasi, Jati Sempurna, Medan Satria, Pondok Gede and Pondok Melati Districts are; Lack of Capital and Limited Access to Finance, Quality of Human Resources, Weak Business Network and Market Penetration Ability, SME Entrepreneur Mentality, Lack of Management Transparency, Absence of Financial Management, Lack of Cooperation with Financial Institutions, Business Climate Not Completely Conducive, Limited Facilities and Business Infrastructure, Illegal Levies, Implications of Regional Autonomy, Implications of Free Trade, Nature of Products with Short Resilience, Limited Market Access, Limited Access to Information (Ministry of Cooperatives and SME of the Republic of Indonesia, 2012). Marketing strategy that is less than optimal, due 
to high marketing costs, lack of distribution access, and adequate marketing media so that the products / services offered are less attractive to consumers.

In relation to the aforementioned conditions, it is necessary to develop a holistic marketing governance model, to compete in a competitive market.

In some previous studies, the performance of SME can be improved by the competence of their human resources. Some have questioned the management and organizational development model. The problem in this study is what kind of SME business management model can improve the performance of SME in Bekasi.

\section{LITERATURE REVIEW}

The Holistic Marketing Concept according to Kotler and Keller (2013) is a marketing concept that is often used at the end of this decade. There are 4 components in this marketing orientation, namely relationship marketing, integrated marketing, internal marketing and social responsibility marketing. Company performance is the result of many individual decisions made continuously by management (Mulyadi, in Hanuma, 2010). To measure company performance, Kotler and Keller (2013) suggest that it is based on Return On Invesment not on profit margins.

The House Model raises a hidden business vision, which is no longer just about looking for personal gain, but has a vision to become a business unit that can provide jobs or empower the surrounding community so that they have a decent income (Putri W, Anggraeni S, Lindawati $\mathrm{K}$, 2014). The application of The House Model has driving and inhibiting factors. The driving factor for the SME performance improvement model is the availability of the quantity of human resources; product uniqueness; access and supporting infrastructure; capital assistance from various parties; development of specific products, close kinship and short managerial hierarchies. On the other hand, the inhibiting factors for the SME performance improvement model are the low competency and motivation of human resources; lack of supervision of implementation standards; limited use of technology for marketing; low willingness of owners to access capital information; there is no clear job description; less strict sanctions; and the complexity of the bureaucracy.

The new SME business management model is a business management system consisting of a holistic marketing and financial management subsystem that can be implemented in SME in the field of products and services which are expected to improve the performance of these SME.. Research I.D.K.R. Ardiana, I.A. Brahmayanti, Subaedi (2010) found that together the three variables have a significant effect on the performance of SME in the city of Surabaya.. Of the three competency variables consisting of knowledge, skills and knowledge, it turns out that the ability variable has the most dominant influence on the performance of SME in the city of Surabaya. Other researchers such as S. Ariawan et al (2017), found a model of SME management that the implementation of appropriate and appropriate strategies used by Karawo SME is the most dominant cost leadership strategy then the second differentiation strategy. Based on the test results, it is found that the cost leadership strategy has a significant effect on the performance of SME. This is in accordance with the conditions of SME Karawo which is the main commodity in the SME development program.

The desire of small and medium enterprises to overcome the sluggishness of the SME business is a solution to how to ensure the sustainability of the SME business so that it has high competitiveness. This research can produce a business management model for products and services that can be easily implemented in SME. In 2020, researchers will focus more on researching the development of a business management model that focuses on holistic marketing management as the most important instrument in improving and measuring SME business performance.. 
A holistic marketing program consisting of four variables, namely relationship marketing, integrated marketing, internal marketing and social responsibility marketing, must be carried out simultaneously to maintain and increase the SME market share. The holistic marketing program emphasizes that all organizational units move together by using their resources to achieve business success. Thus the effectiveness of the holistic marketing program will improve the performance of the SME business.

Relationship marketing is building quality long-term relationships with steakholders with the aim of being able to generate and sustain business in a sustainable manner. The four key constituents in relationship marketing are customers, employees, partners, and the financial community.

Integrated marketing is sharing marketing activities and unifying marketing programs to create, communicate and deliver value to consumers on the principle that overall is better. There are two themes, namely (1) many different marketing activities can be create, communicate and convey value and (2) marketers must design and implement marketing activities with other activities.

Internal marketing is an element of holistic marketing, by hiring, training, and motivating employees who want to serve customers well. Ensuring that everyone in the company understands marketing principles well, especially senior management. Smart marketers recognize that in-company marketing activities are very important, as important or even more important than marketing outside the company.

Performance marketing requires an understanding of material and non-material returns to companies and communities through marketing programs and activities. Top marketers are beginning to look further into not just increasing sales, but in assessing the achievement of marketing results and translating what is happening and is seen in market share, customer loss, customer satisfaction, product quality and other measures. They also consider the legal, social and environmental impacts of marketing programs and activities.

SME who use a holistic marketing governance model consistently and effectively will produce good business performance. The more effective the holistic marketing governance is, the more it will improve the performance of the SME business.

Several studies on the performance of SMEs that have been conducted by researchers in the past, are presented with the results of previous studies, namely; I.D.K.R. Ardiana, I.A. Brahmayanti, Subaedi (2010) with SME HR Competencies and Their Impact on SME Performance in Surabaya, found that the competence of SME HR has a significant relationship to the performance of SME. This is also supported by the results of the analysis of determination. The influence of the knowledge variable turns out to be insignificant on the performance of SME because the value is negative and very small, However, the other two variables, namely skills and abilities, have a significant influence so that these two variables need to be considered in developing the performance of SME. Of the three competency variables consisting of knowledge, skills and knowledge, it turns out that the ability variable has the most dominant influence on the performance of SME in the city of Surabaya.

I.P.L.E Sudiarta et al (2014) in the results of the study show that there are two factors that affect the performance of SME in Bangli Regency, namely: (1) internal factors, and (2) external factors. The most dominant factors affecting the performance of SME in Bangli Regency are internal factors, which include: marketing, access to capital, entrepreneurial skills, human resources, financial knowledge and business plans.. 
Noor Azmi bin Hashim, Saqlain Raza, Mohd Sobri Minai (2018), Relationship between, Entrepreneurial Competencies and Small Firm Performance: Are Dynamic Capabilities the Missing Link? found that for better performance of small firms, entrepreneurial competence and dynamic capabilities were considered prospective solutions. In addition, economic fluctuations with volatile and unpredictable markets, dynamic capabilities are considered an important factor to influence the performance of small companies.

\section{RESEARCH METHODOLOGY}

This reset relates to an effort to examine the effect of independent variables proxied by the construct of a holistic marketing governance model on the performance of SME.

The research population is 700 SME business managers and players domiciled in Bekasi Regency, West Java, and the number will be narrowed based on their business turnover. The samples chosen are managers and business people who have a high school, undergraduate or postgraduate level and have at least 1 year of work experience, and have a position in the field of SME Marketing. The sample was selected by purposive sampling, namely the sample in accordance with the desires of the research objectives as many as 232 respondents

Data collection was carried out by distributing questionnaires through outreach and training activities to respondents. The questionnaire contains questions related to the holistic marketing governance model and the performance of the SME under study.

The independent variables of the holistic marketing model are relationship marketing (RM), integrated marketing (IGM), internal marketing (IM) and performance marketing (PM), which are simultaneously measured through the perceptions of SME business actors using the Likert scale.

Dependent variable is the level of performance of SME as a result of the actions or activities of the company by determining certain measures such as sales, company revenue, target market, solvency ratio, profitability, liquidity and profitability which can measure the success of an SME company as measured through the perceptions of the actors. SME businesses using a Likert scale

The location of this research is on SMEs in the Bekasi district, while the provision of Holistic Marketing Governance for SME products is carried out in the Hall of the Office of Cooperatives and Trade of the Bekasi Regional Government.

The approach to modeling and solution techniques used as an analysis tool in this dissertation is to use SEM (Ghozali, Imam and Fuad, 2014). The reason for choosing this method is because of its ability to measure constructs indirectly, namely through its indicators as well as analyzing indicator variables and latent variables.

SEM can be analyzed the relationship between indicators and their latent variables known as the measurement equation, and the relationship between one variable and another latent variable known as the structural equation, together involving measurement errors. In SEM, the dependent variable is also called an endogenous variable, while the independent variable is also called an exogenous variable.

SEM analysis will provide a clear picture of the relationship and the magnitude of the influence between the research variables which is very useful for explaining in detail the various factors that can improve the performance of the SME business. The research design that will be used in this research is in accordance with the research objectives to be achieved.

Figure 1. Structural Model 


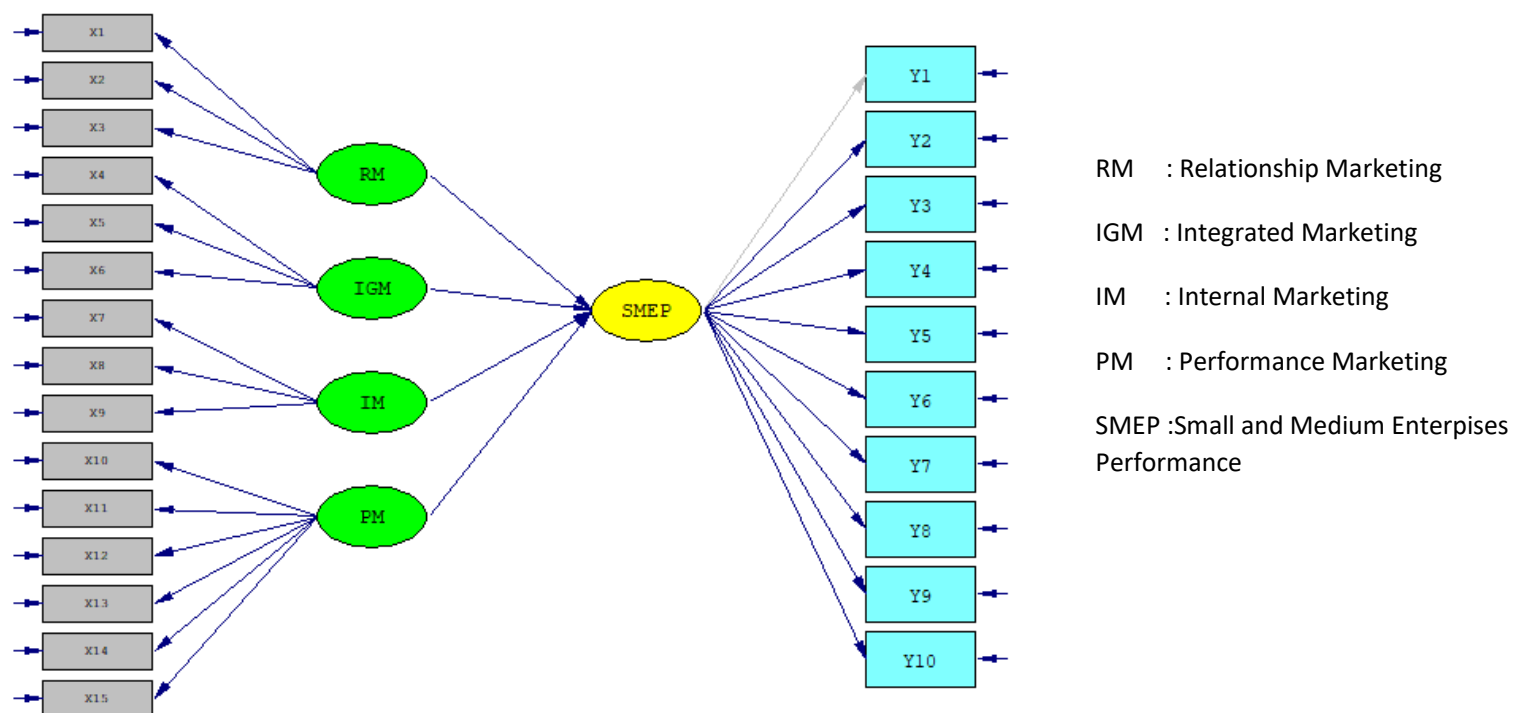

Source : Output Lisrel 8.8 (2021)

Table 1. Summary of SEM Calculation Results on Structural Equation Models

\begin{tabular}{|c|c|c|c|c|c|c|}
\hline \multicolumn{2}{|c|}{ Equation of Measurement } & \multirow{2}{*}{$\begin{array}{c}\text { Path } \\
\text { Coefficient } \\
\text { (Standardize } \\
\text { d) }\end{array}$} & \multirow{2}{*}{$\begin{array}{c}\text { Standar } \\
\text { Error (SE) }\end{array}$} & \multirow{2}{*}{$\begin{array}{l}\text { The value } \\
\text { of } t \\
\text { calculate }\end{array}$} & \multirow{2}{*}{$\begin{array}{l}\text { Test results } \\
(\alpha=0,05)\end{array}$} & \multirow{2}{*}{$\mathrm{R}^{2}$} \\
\hline $\begin{array}{l}\text { Latent } \\
\text { Variable } \\
\text { Endogen }\end{array}$ & $\begin{array}{l}\text { Latent } \\
\text { Variable } \\
\text { Exodogen }\end{array}$ & & & & & \\
\hline \multirow[t]{4}{*}{$\begin{array}{l}\text { SME Per- } \\
\text { formace }\left(\eta_{1}\right)\end{array}$} & $\begin{array}{l}\text { Relation-ship } \\
\text { Mar-keting }\left(\xi_{1}\right)\end{array}$ & $\gamma_{1}$ & $\zeta_{1}$ & $\gamma 1 / \zeta_{1}$ & $\begin{array}{l}\text { Signifi- } \\
\text { cant/Not }\end{array}$ & \\
\hline & $\begin{array}{l}\text { Intergrated } \\
\text { Marketing }\left(\xi_{2}\right)\end{array}$ & $\gamma_{2}$ & $\zeta_{1}$ & $\gamma_{2} / \zeta_{1}$ & $\begin{array}{l}\text { Signifi- } \\
\text { cant/Not }\end{array}$ & \\
\hline & $\begin{array}{l}\text { Internal } \\
\text { Marketing }\left(\xi_{3}\right)\end{array}$ & $\gamma_{3}$ & $\zeta_{1}$ & $\gamma 3 / \zeta 1$ & $\begin{array}{l}\text { Signifi- } \\
\text { cant/Not }\end{array}$ & \\
\hline & $\begin{array}{l}\text { Performance } \\
\text { Mar-keting }\left(\xi_{2}\right)\end{array}$ & $\gamma_{4}$ & $\zeta_{1}$ & $\gamma_{4} / \zeta 1$ & $\begin{array}{l}\text { Signifi- } \\
\text { cant/Not }\end{array}$ & \\
\hline
\end{tabular}

Source : Ghozali dalam Supranto, J\&Nandan L (2013:131)

The hypothesis that is built is:

$\mathrm{H}_{1}$ : There is an effect of Relationship marketing on the performance of SME

$\mathrm{H}_{2}$ : There is an effect of Intergrated marketing on the performance of SME

$\mathrm{H}_{3}$ : There is an effect of Internal marketing on the performance of SME

$\mathrm{H}_{4}$ : There is an effect of performance marketing on the performance of SME 
$\mathrm{H}_{5}$ : There is a simultaneous influence of a holistic marketing program (relations marketing, integrated marketing, international marketing and performance marketing) on the performance of SME.

\section{RESULTS AND DISCUSSION}

Based on the results of the analysis with Lisrel 8.80, the overall structural equation model is obtained as shown in Figure 2 and Figure 3 below;

Figure 2. Model Strukktur Standardized

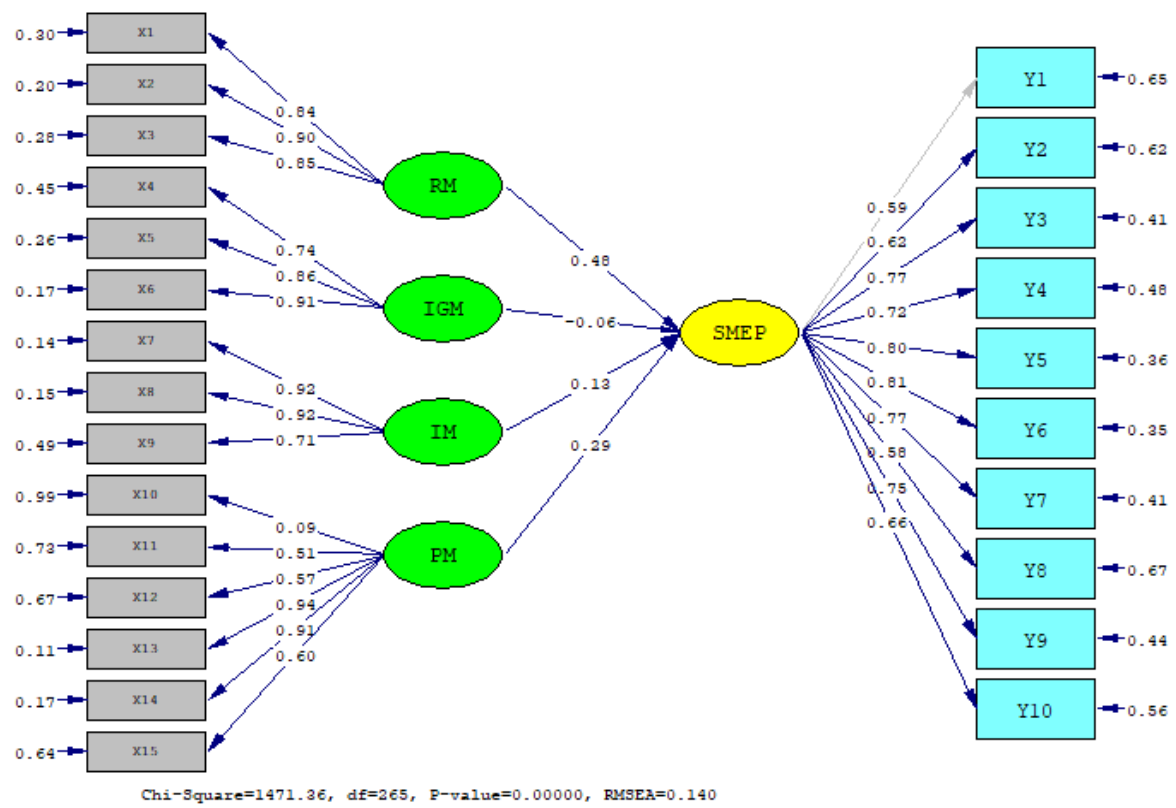

Figure 2. Model Struktural

Source : Output Lisrel 8.8 (2021)

Figure 3. Model Struktural $t$-value 


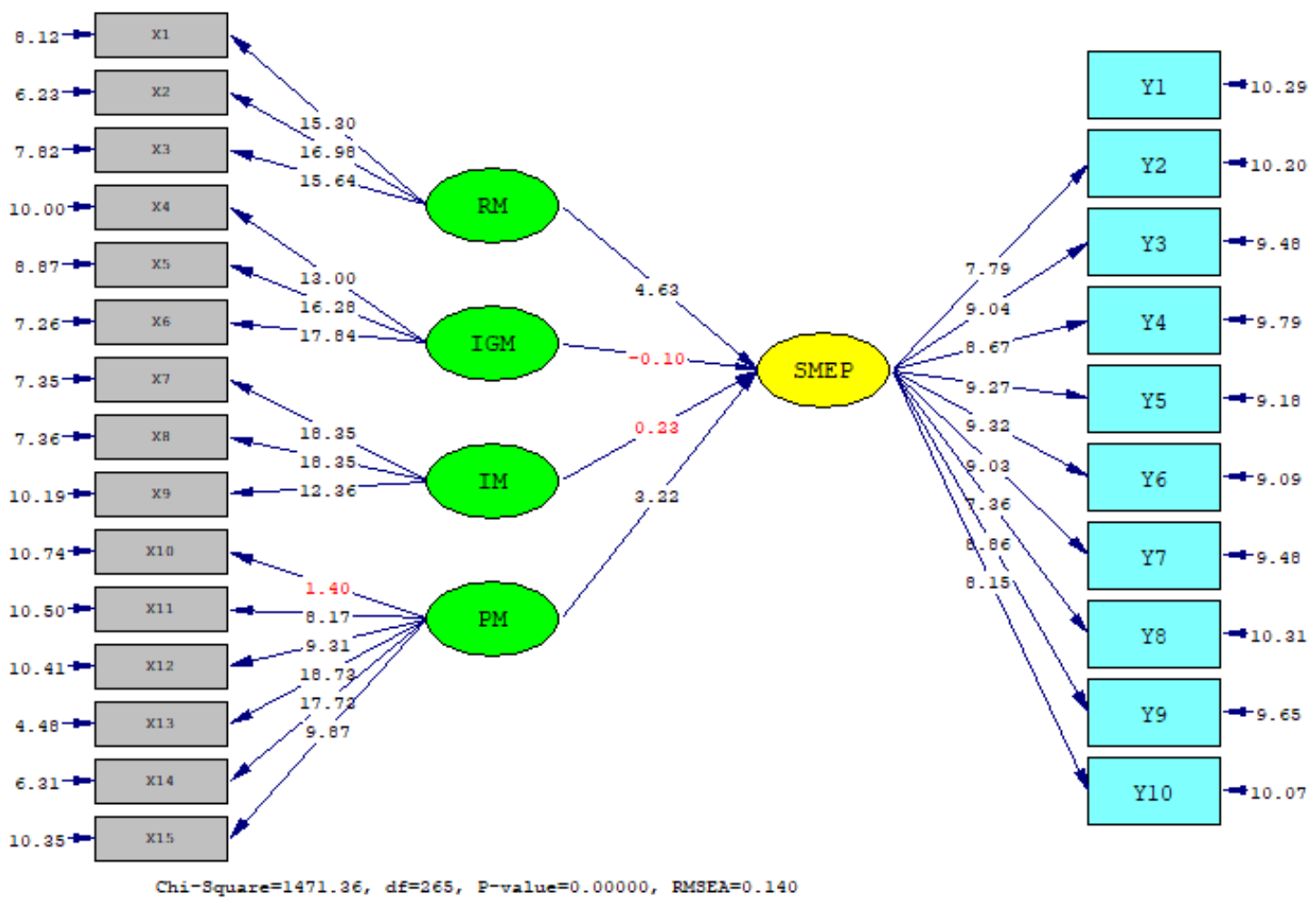

Source : Output Lisrel 8.8 (2021)

Based on Figures 2 and 3, it can be seen that there is an effect of the independent variable on the dependent variable. The results of testing the significance of the influence between latent variables can be seen in Table 2 below. In table 2, the resulting coefficient value and the $\mathrm{t}$-count value are shown. If the structural path has a $t$-value $\geq 1.96$, then the coefficient of the path is significant, and if the t-count $<1.96$, it is concluded that the coefficient of the path is not significant.

Table 2. Significance Between Variables

\begin{tabular}{|c|l|c|c|r|c|}
\hline No & \multicolumn{1}{|c|}{ Structural path } & Path coeffi-cient & t-count & t-table & $\begin{array}{l}\text { Results of } \\
\text { testing }\end{array}$ \\
\hline 1 & $\begin{array}{l}\text { Relations Marketing -> } \\
\text { SME Performance }\end{array}$ & 0,48 & 4,63 & 1,96 & $\begin{array}{c}\text { Signifi } \\
\text { cant }\end{array}$ \\
\hline 2 & $\begin{array}{l}\text { Integrated Marketing -- } \\
\text { SME Performance }\end{array}$ & $-0,06$ & $-0,10$ & 1,96 & $\begin{array}{c}\text { In signifi } \\
\text { cant }\end{array}$ \\
\hline 3 & $\begin{array}{l}\text { Internal Marketing --> } \\
\text { SME Performance }\end{array}$ & 0,12 & 0,23 & 1,96 & $\begin{array}{c}\text { In ignifi } \\
\text { cant }\end{array}$ \\
\hline 4 & $\begin{array}{l}\text { Performance Marketing } \\
-->\text { SME Performance }\end{array}$ & 0,29 & 3,22 & 1,96 & Signifi \\
\hline
\end{tabular}


Source : Output LISREL 8.80

Based on the output obtained using the Lisrel 8.80 program for structural models (standardized and t-value models) and structural equations, according to the four hypotheses proposed above can be seen as below.

Structural Equations:

SMEP $=0.48 * \mathrm{RM}-0.06 * \mathrm{IGM}+0.13 * \mathrm{IM}+0.29 * \mathrm{PM}$,

Errorvar. $=0.47, \mathrm{R}^{2}=0.53$

$\begin{array}{llll}4.63 & -0.010 & 0.23 & 3.22 \\ & & & 4.58\end{array}$

The first hypothesis $\left(\mathbf{H}_{1}\right)$ states that relationship marketing has an effect on SME performance. The results of the structural equation above, it can be seen that the loading factor (path coefficient) of the Relations Marketing variable on SME performance is 0.48 with a tcount of 4.63> 1.96, so it can be said to be significant. The amount of the path coefficient indicates that the magnitude of the influence of Relations Marketing directly on SME performance is 0.48 or 48\%. This shows that the SME Relations Marketing program has been good, especially in building relationships with distributors so that it has a positive and significant effect in improving SME performance.

The second hypothesis $\left(\mathbf{H}_{2}\right)$ states that integrated marketing has a negative effect on SME performance. The results of the structural equation above, it can be seen that the path coefficient of the Integrated marketing variable on SME performance is -0.06 with a tcount of $0.23<1.96$, so it can be said to be negative and insignificant. The amount of the path coefficient indicates that the magnitude of the direct influence of integrated marketing on SME performance is -0.06 or $-6 \%$. It can be said that integrated marketing towards SMEs is negative in improving the performance of SMEs. Then there is no significant effect of integrated marketing on the performance of SMEs, indicating that directly integrated marketing will reduce the performance of SMEs.

The third hypothesis $\left(\mathbf{H}_{3}\right)$ states that internal marketing has an effect on SME performance. The results of the structural equation above, it can be seen that the loading factor (path coefficient) of the Internal Marketing variable on SME performance is 0.12 with a tcount of $0.23<1.96$, so it can be said to be insignificant. The amount of the path coefficient indicates that the magnitude of the direct influence of internal marketing on SME performance is 0.12 or 12\%. This shows that the internal SME Marketing program has not been good, especially in providing an understanding of products / services to leaders and staff outside the marketing field, so that it has a positive but insignificant effect in improving SME performance.

The fourth hypothesis $\left(\mathbf{H}_{4}\right)$ states that performance marketing affects the performance of SMEs. The results of the structural equation above, it can be seen that the loading factor (path coefficient) of the marketing performance variable on the performance of SMEs is 0.29 with a tcount of $3.22>1.96$, so it can be said to be significant. The amount of the path coefficient indicates that the magnitude of the influence of performance marketing directly on the performance of SMEs is 0.29 or $29 \%$. This shows that the SME performance marketing program is quite good, especially in terms of environmental concern, so that it has a positive and significant effect in improving SME performance. 
The fifth hypothesis (H5) states that relationship marketing, integrated marketing, international marketing and performance marketing together have an effect on the performance of SMEs. The results of the structural equation above, it can be seen that the coefficient of determination (R2) of the four exogenous variables jointly affects the performance of SMEs is 0.53 with an Fcount of $4.58>3.84$, so it can be said to be significant. The amount of the coefficient of determination (R2) shows the amount of the contribution of Relations marketing, Integrated marketing, International marketing and Performance marketing together to SME performance by $53 \%$, while the remaining $47 \%$ is an influencing factor outside the variables Relations marketing, Integrated marketing, International marketing. and Performance marketing. The variable that most dominantly affects the performance of SMEs is the relationship marketing variable. This explains that the better the relationship with customers, distributors and other partners will improve the performance of SMEs.

\section{CONCLUSIONS AND SUGGESTIONS}

1. It is proven that relations marketing has an effect on SME performance, especially in building relationships with distributors.

2. It is not proven that integrated marketing has an effect on SME performance, because the path coefficient is -0.06 and not significant.

3. It is proven that internal marketing has an effect on SME performance, but not significantly.

4. It is proven that performance marketing has an effect on the performance of SMEs, especially in caring for the surrounding environment.

5. It is proven that relationship marketing, integrated marketing, international marketing and performance marketing together have an effect on the performance of SMEs, with a contribution value of 53\%. The variable that most dominantly affects the performance of SMEs is the relationship marketing variable.

Based on the above conclusions, the researcher provides suggestions for future SMEs and further researchers, as follows:

1. To improve the performance of SMEs, businesses should build good relationships with distributors by cooperating on a contractual basis.

2. To improve the performance of MSMEs, the integrated marketing program should be improved by building marketing communication networks, digital marketing and improving the quality of product / service innovation offered.

3. To improve the performance of SMEs in a sustainable manner, SMEs should strive to provide understanding and motivation to leaders and employees in the marketing and other fields.

4. To improve the performance of SMEs, it is better if the Corporate social responsibility program is carried out in the form of financial and physical assistance in the surrounding environment.

5. For the next researchers, can re-examine the performance of SMEs, by changing and adding different variables such as employee competence, product / service quality, excellent service, and other research objects.

\section{REFERENCES}

Ghozali, Imam and Fuad. (2014). Structural Equation Modeling. Theory, Concepts, and Applications with the Lisrel 8.80 Program. 4th edition, Semarang: Diponegoro University. 
I.D.K.R. Ardiana, I.A. Brahmayanti, Subaedi (2010) SME HR Competencies and Their Effects on SME Performance in Surabaya, Journal of Management and Entrepreneurship, Vol.12, No. 1, Mart 2010: 42

I.P.L.E Sudiarta at.all (2014), Analysis of Factors Affecting the Performance of Micro, Small and Medium Enterprises (SMEs) in Bangli Regency, e-Journal Gajah Mada University of Education Department of Management Vol. 2 of 2014.

Kotler, P \& KL. Keller, (2013) Marketing Management, England: Pearson Horizon.

Noor Azmi bin Hashim, Saqlain Raza, Mohd Sobri Minai (2018), Relationship between, Entrepreneurial Competencies and Small Firm Performance: Are Dynamic Capabilities the Missing Link? Academy of Strategic Management Journal, April 1, 2018

Peningkatan Kinerja Usaha Kecil dan Menengah (UKM) Kluster Kerajinan

di Kota Depok Menggunakan The House Model

Peningkatan Kinerja Usaha Kecil dan Menengah (UKM) Kluster Kerajinan

di Kota Depok Menggunakan The House Model

Peningkatan Kinerja Usaha Kecil dan Menengah (UKM) Kluster Kerajinan

di Kota Depok Menggunakan The House Model

Putri W, Anggraeni S, Lindawati K, (2014), Improving the Performance of Small and Medium Enterprises (SMEs) in the Craft Cluster in Depok City Using The House Model, Journal of Management and Organization Vol V, No. 2, August 2014

Supranto J and Nandan Lima Krisna. 2013. Practical Instructions for Scientific Research to Prepare Thesis and Dissertation Thesis, Jakarta: Mitra Wacana Media.

S. Ariawan, D Made, G Mackie (2017), Implementation of Business Strategies to Improve SME Performance (Study of Karawo SME in Gorontalo City), SME Business Strategy Journal.

Soraya Hanuma Endang Kiswara (2010) Analysis of the Balance Scorecard as a Measuring Tool for Company Performance (Case Study at PT Astra Honda Motor), Research Published. Semarang: Faculty of Economics, Diponegoro University. 